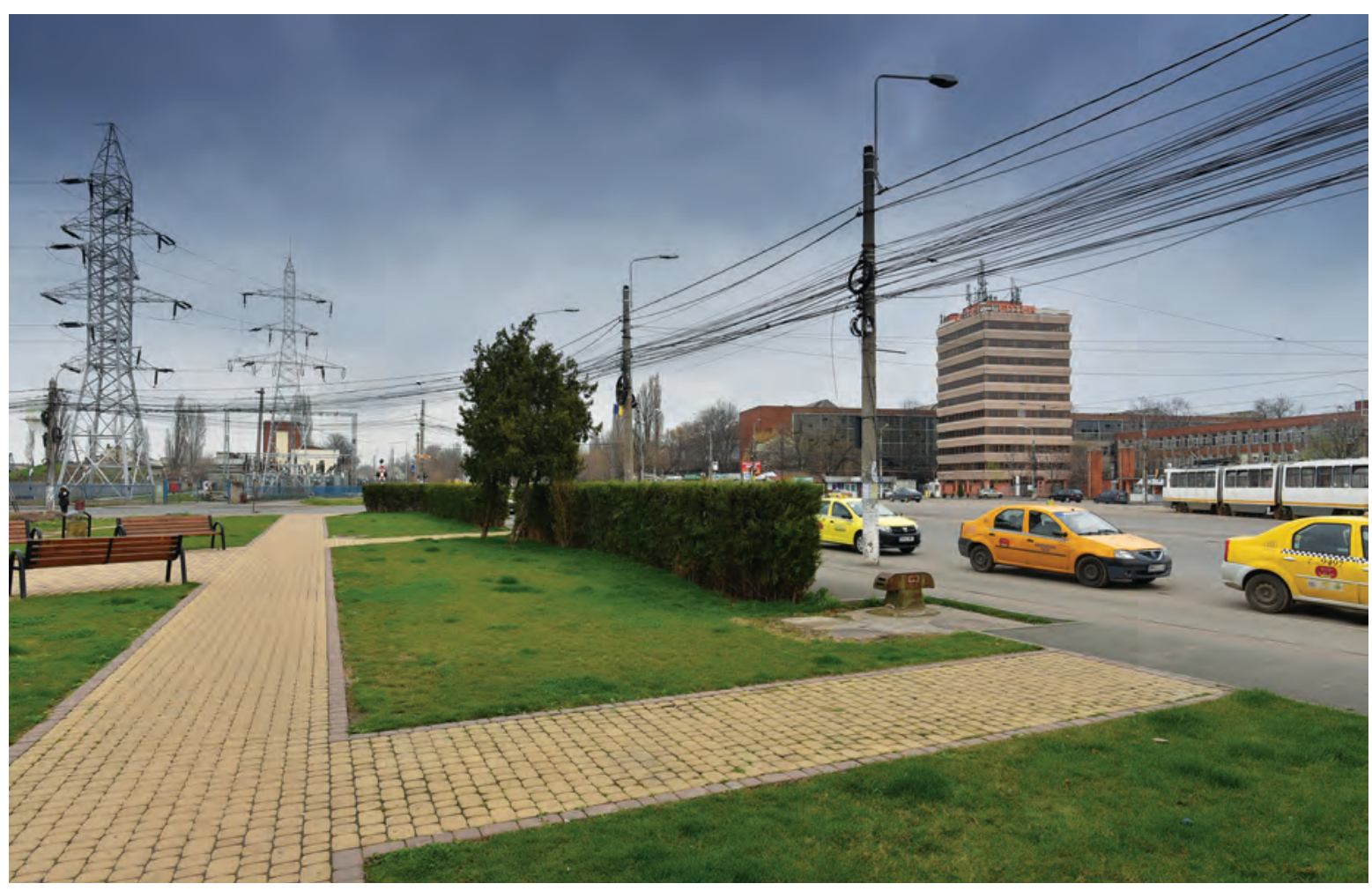

echipa de lucru /

work team:

Andrei LAKATOS

arhitect / architect

Maria BOȘTENARU-DAN

arhitect / architect

Reka CSAPO DUP, Darie DUP

artiști / artists

Locul are ca amprentă fostul centru industrial (local, dar și național), de mare prestigiu. Odată abandonată această funcțiune, post 1990, el are nevoie de o idee de revitalizare, poate în direcția unui mall cultural sau campus studențesc, infuzie de viu de care zona ar putea profita din plin. $O$ emblemă a zonei, aici, trebuie să fie o marcă a viitorului.

The place has as landmark the former industrial center (local and national), building of great prestige. Once this function abandoned, after 1990, it needs an idea of revitalization, maybe in the direction of a cultural mall or student campus, life infusion from which the area could take full advantage. An emblem of the area, here, must be a mark of the future. 


\section{Andrei LAKATOS}

Pergola

Legat de proiectul pentru spațiul public de la stația de metrou Republica, eu personal nu văd neapărat un obiect de artă acolo, ci o amenajare de spațiu public, care să dea sens locului, să îl facă mai accesibil și plăcut, dar care să aibă și o anumită semnificație, ca un semnal-simbol. Fix pe diagonală față de stația de metrou se află Hala Laminor, proiectată de arhitectul Horia Creangă, în prezent clasată ca monument de arhitectură, dar care se află într-o stare foarte avansată de degradare. Ea a fost un reper puternic în zonă, ca de altfel tot arealul fostei Uzine Republica (sau Uzinele Malaxa), unde foarte multă lume din cartier a lucrat pentru mulți ani. De aceea, propunerea mea ar fi o structură metalică de tip pergolă, care să acopere/unifice spațiile (gura de metrou, accesul către peronul gării, micul „scuar” de lângă gura de metrou). Structura preia într-un mod sintetic linia și motivul fermelor metalice ale Halei Laminor, reduse la scară, devenind elementul ordonator, unificator și de reper al amenajării, dar și al zonei pe care o deservește. Spațiul de sub structură devine unul versatil, în relație cu utilizările actuale ale locului: copertină pentru gura de metrou și accesul către peron, zonă acoperită sau descoperită pentru spațiul de întâlnire și așteptare de lângă gura de metrou. Vegetația actuală este păstrată în întregime, urmând ca ea să „străpungă” pergola. De asemenea, spațiul de lângă gura de metrou primește o amenajare simplă, cu bănci de stat, pavele din beton și spațiu verde - gazon.

\section{Pergola}

About the public space project at Republica subway station, I do not necessarily see an art object there, but a public space that makes sense of the place, to make it more accessible and enjoyable, but also having a certain meaning, as a symbolic signal. Diagonally to the subway station we find the Laminor Hall, designed by the architect Horia Creangă, currently ranked as the diagonal of the subway station, now ranked as an architectural monument, but which is in a very advanced state of degradation. It has been a strong landmark in the area, as is the whole area of the former Republic Factory (or Malaxa Plant), where many people from the neighborhood have worked for many years. That's why my proposal would be a pergola metallic structure to cover / unify the spaces (the subway exit, the access to the station platform, the small square next to the subway exit area). The structure continues in a synthetic way the line and the theme of the Hala Laminor's metal farms, reduced to scale, becoming the ordinating, unifying and landmark element of the arrangement, but also of the area that it serves. The space underneath the structure becomes versatile in relation to the current use of the place: subway cover and access to the platform, covered or uncovered area for the meeting and waiting area next to the subway. The current vegetation is preserved in its entirety, and it will be penetrating „the pergola”. Also, the area next to the subway exit receive a simple arrangement, with sitting benches, concrete pavers and green lawns.

(english translation: Măriuca Mănescu)

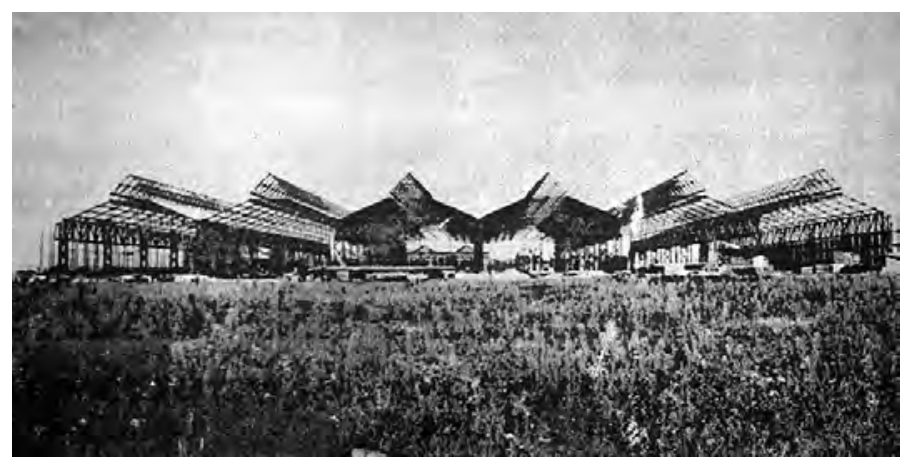

fotografii ale halelor, în epocă și astăzi hall's pictures, working era and today

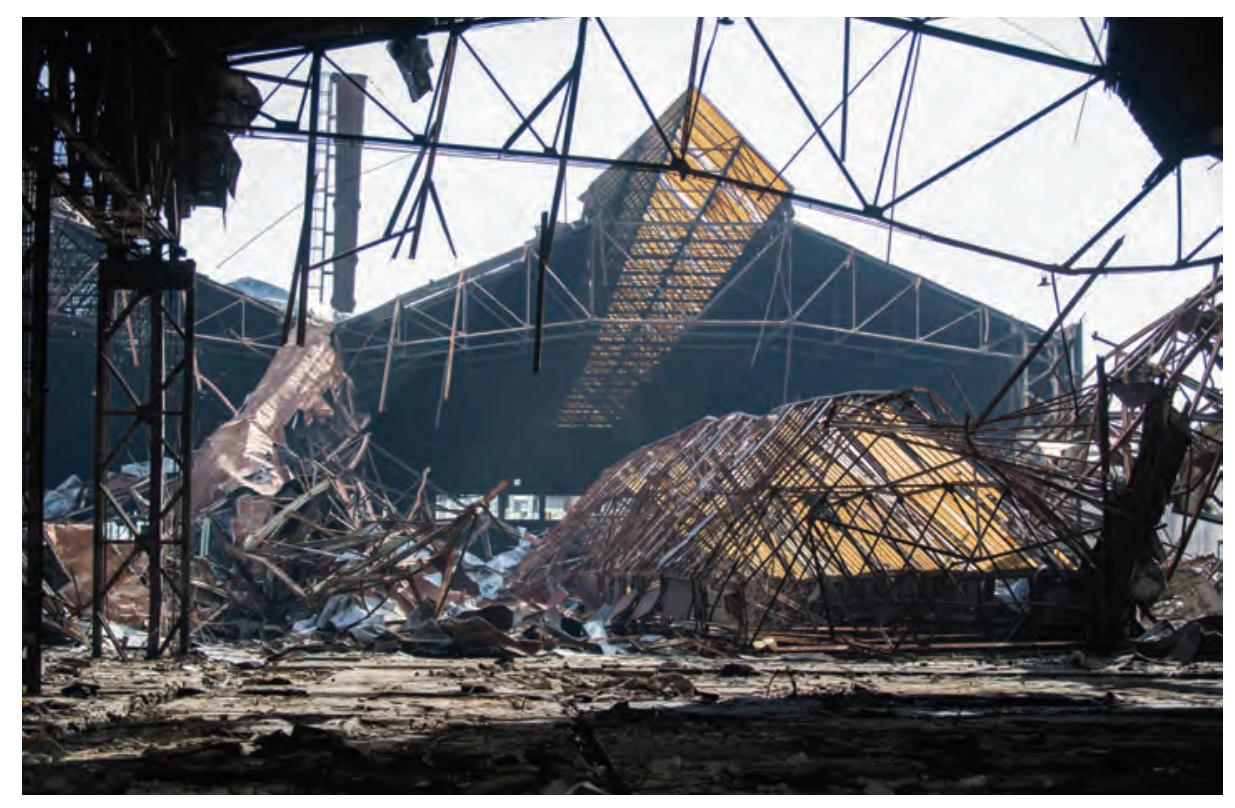


Bucharest, reinvented places / 3rd District
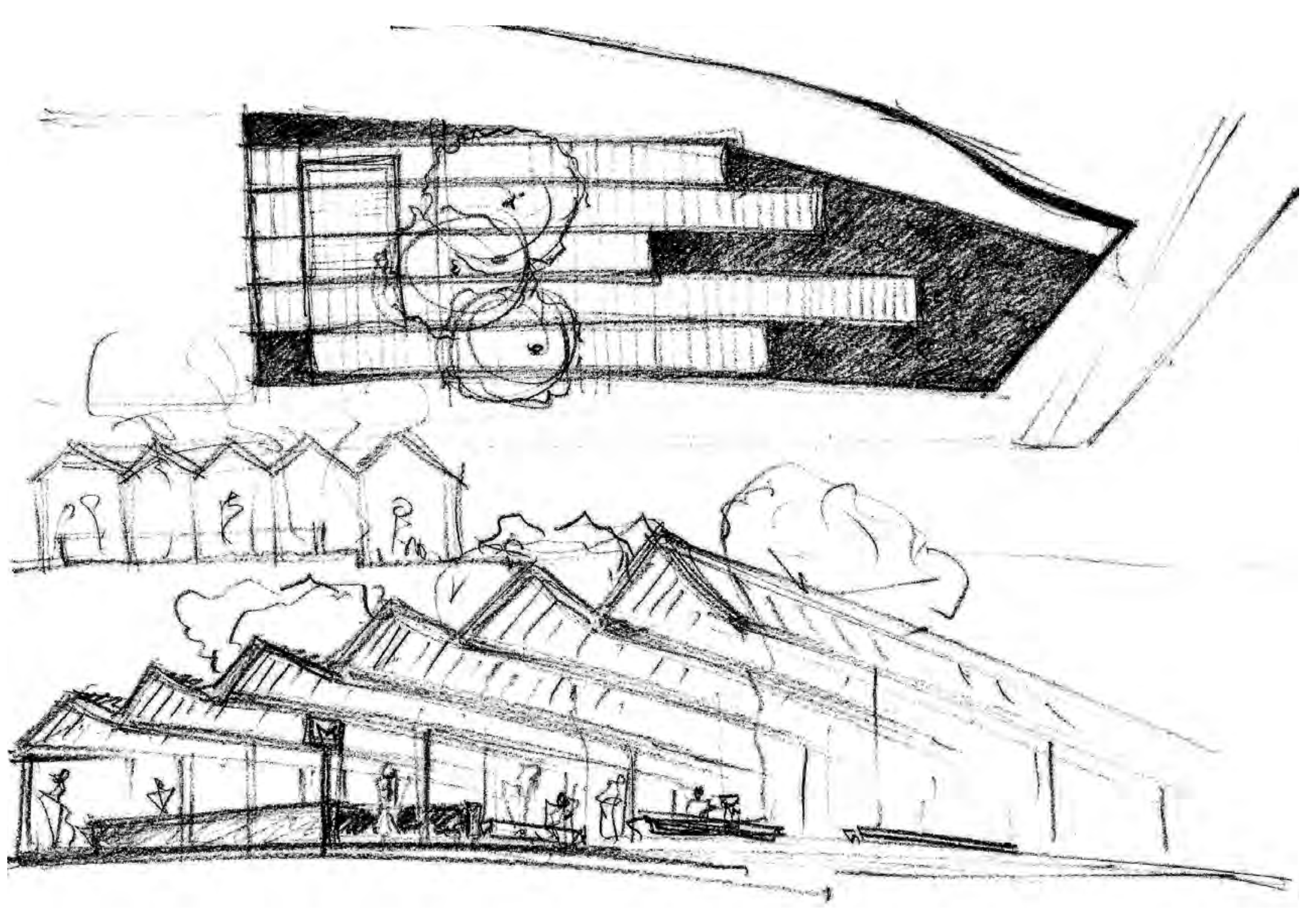

propunere, schiță

proposal, sketch 


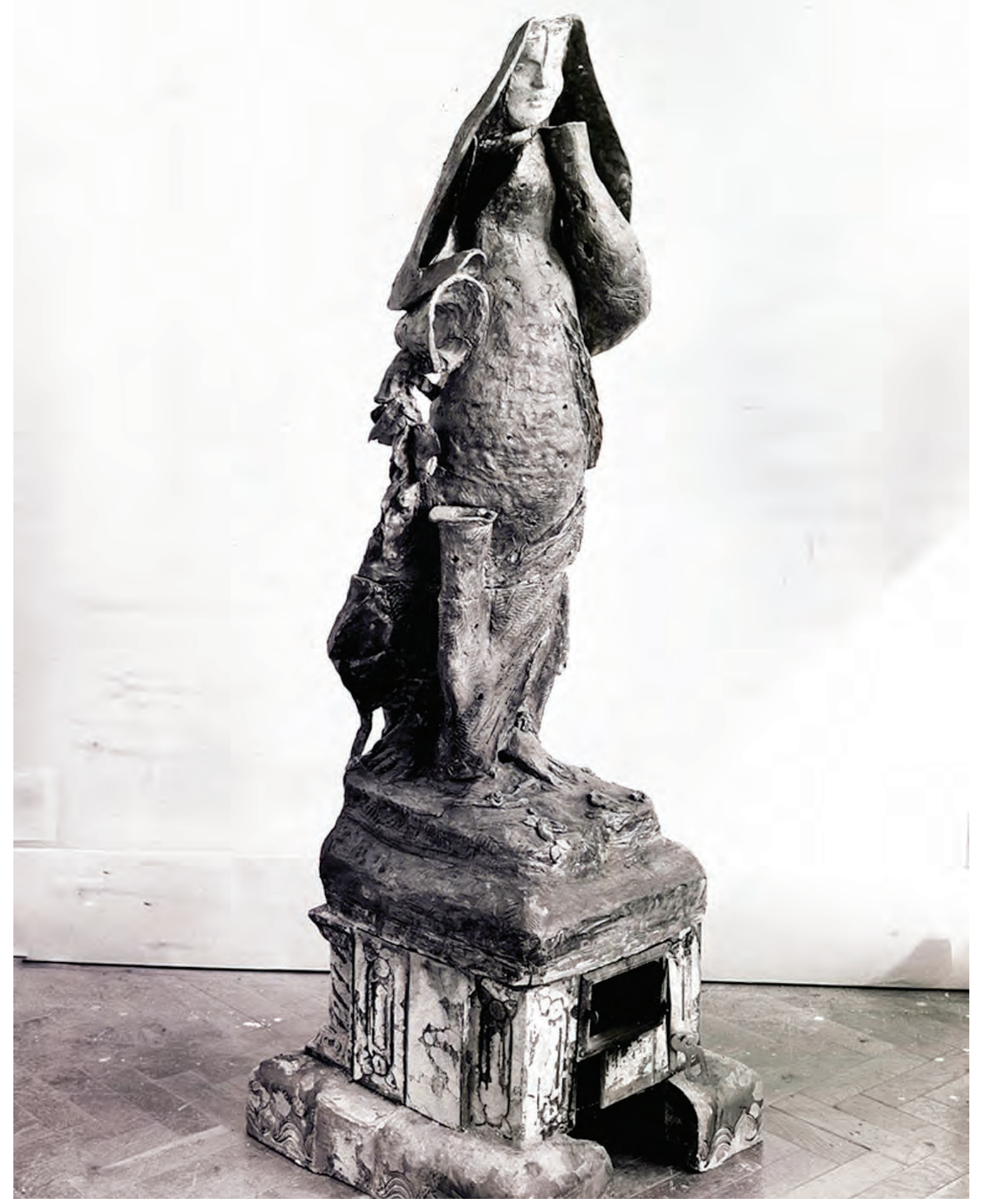

Lucrarea (...) se referă la cercetările mele plastice legate de imagistica madonelor, a vestigiilor religioase eclectice, postmoderne, care au un rol de metamorfoză idolatrică în viața noastră de zi cu zi și, vrând-nevrând, ne conturbă, relevă sau incomodează din vitrinele rețelei citadine.

(Reka Csapo Dup)

The work (...) refers to my plastic research on the imagery of madonna, the eclectic, postmodern religious vestiges having a role of idolatrous metamorphosis in our everyday life and, willy-nilly, disturbing us, revealing us or getting us uncomfortable watching us from the windows of the city network.

(Reka Csapo Dup) 
Bucharest, reinvented places / 3rd District

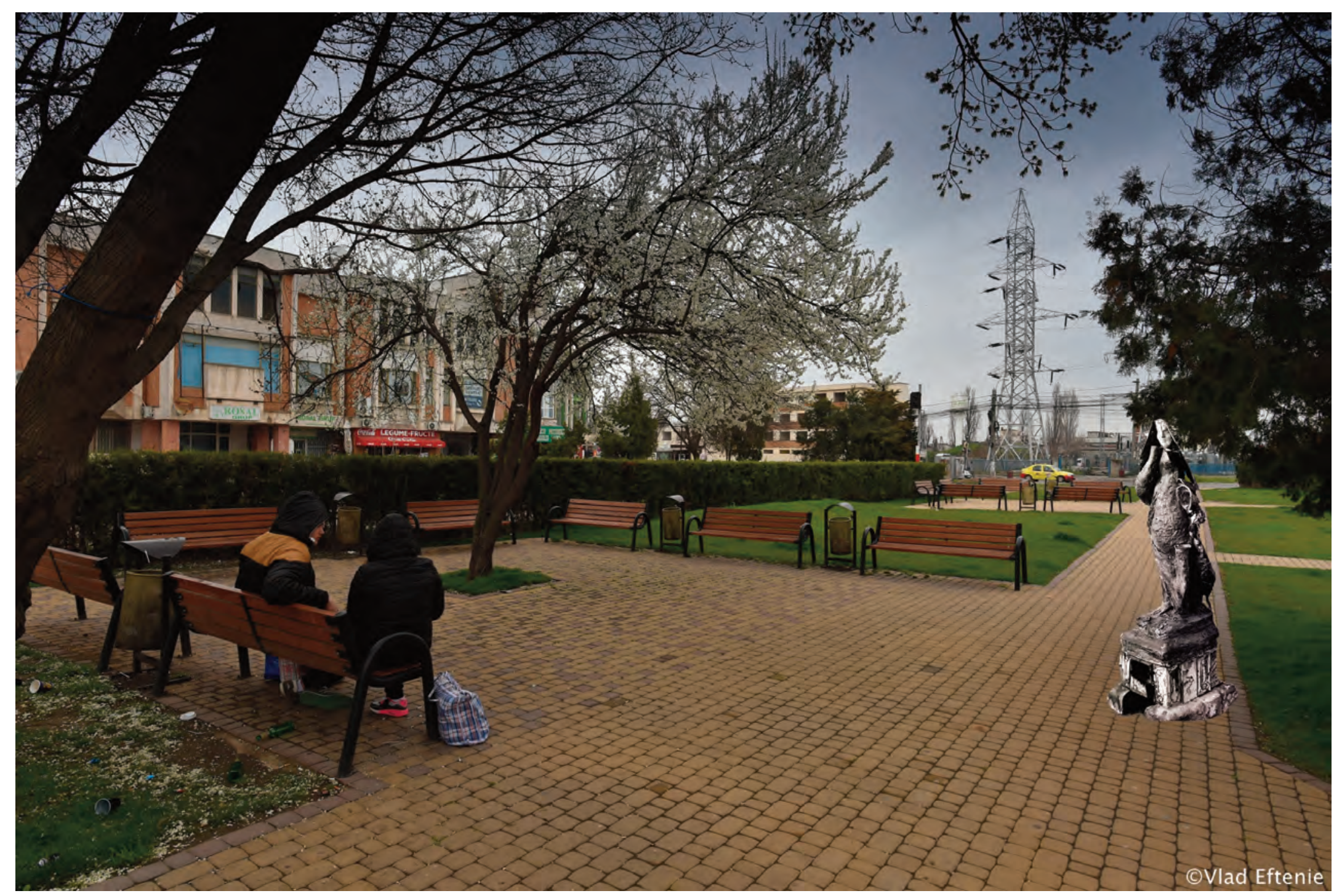

Statuia este o inserție a unui moment istoric în prezent.

The statue is an insert of a historical moment into the present. 


\section{București, locuri reinventate / Sectorul 3}
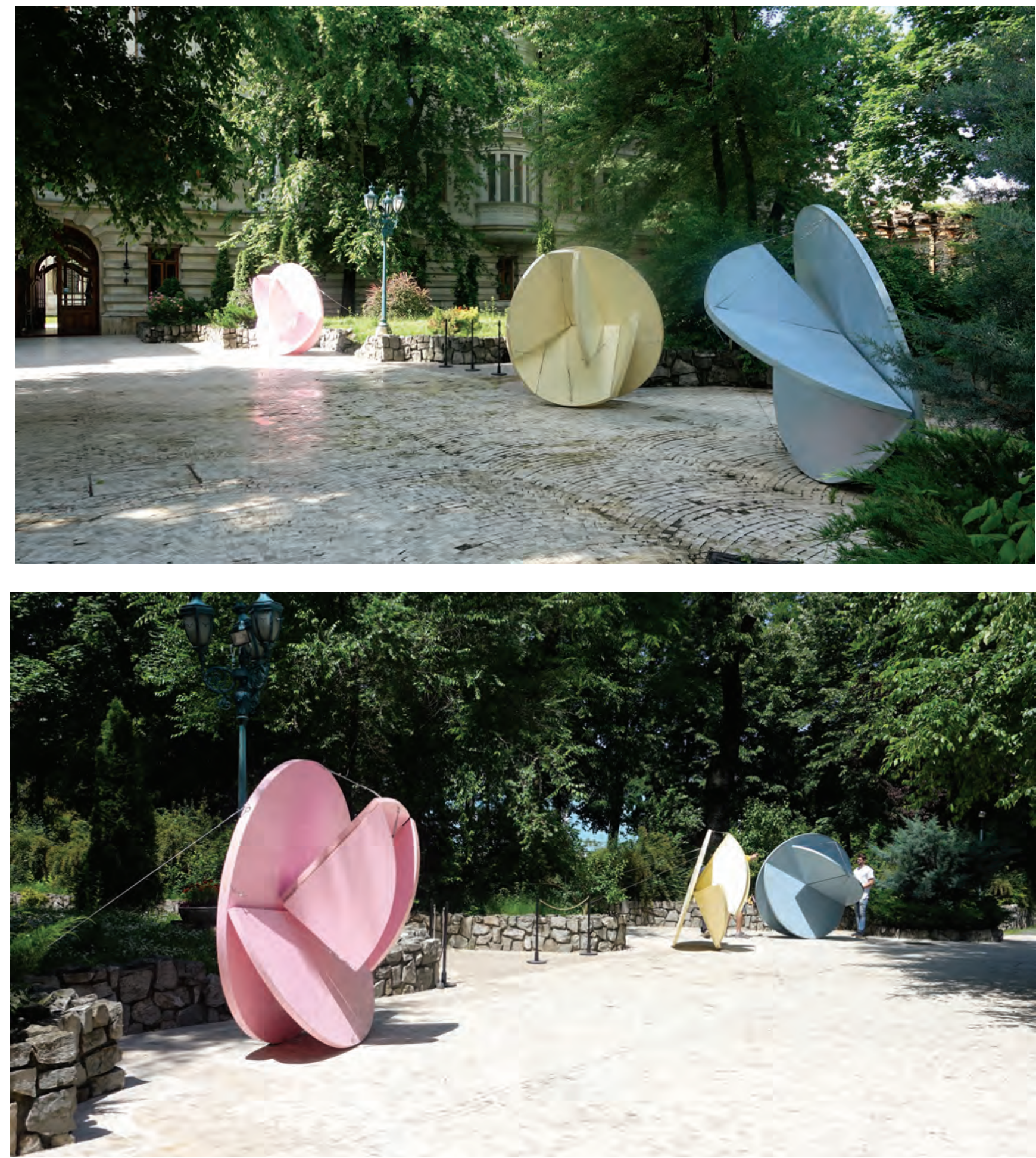

Aceste lucrări, cercuri mari de lemn, sunt de fapt ca niște tăieturi de copac. Am vrut să fac lucruri impersonale ca expresie, dar care să transmită o stare de fapt care o trăim cu toții față de flagelul defrișărilor abuzive și necontrolate. Pe tot parcursul acestui proiect, AXIS MUNDI, care se ocupă de tema ecologică a defrișării abuzive, m-am concentrat la semne foarte clare, geometrice, care să amintească de vegetal, într-o postură minimalistă, fără ca retorica dezastrului ecologic să fie pasională și personală. Cred că Arta poate fi la fel de angajată în social ca oricare din celelalte activități ale omului și cred în forța ei educativă și de însănătoșire spirituală și morală.

(Dup Darie)

These works, large circles of wood, are actually some tree cuts. I wanted to do things impersonal in their expression, but conveying a state of affairs that we all live with the scourge of Throughout this project, AXIS MUNDI, dealing with the ecological theme of abusive deforestation, I focused on very clear, geometric signs, remembering the vegetal in a minimalist posture, without the rhetoric of ecological disaster passionately and personally experienced. I believe that Art can be as socially engaged as any other human activity and believe in its educational and spiritual strength and etic.

(Dup Darie) 


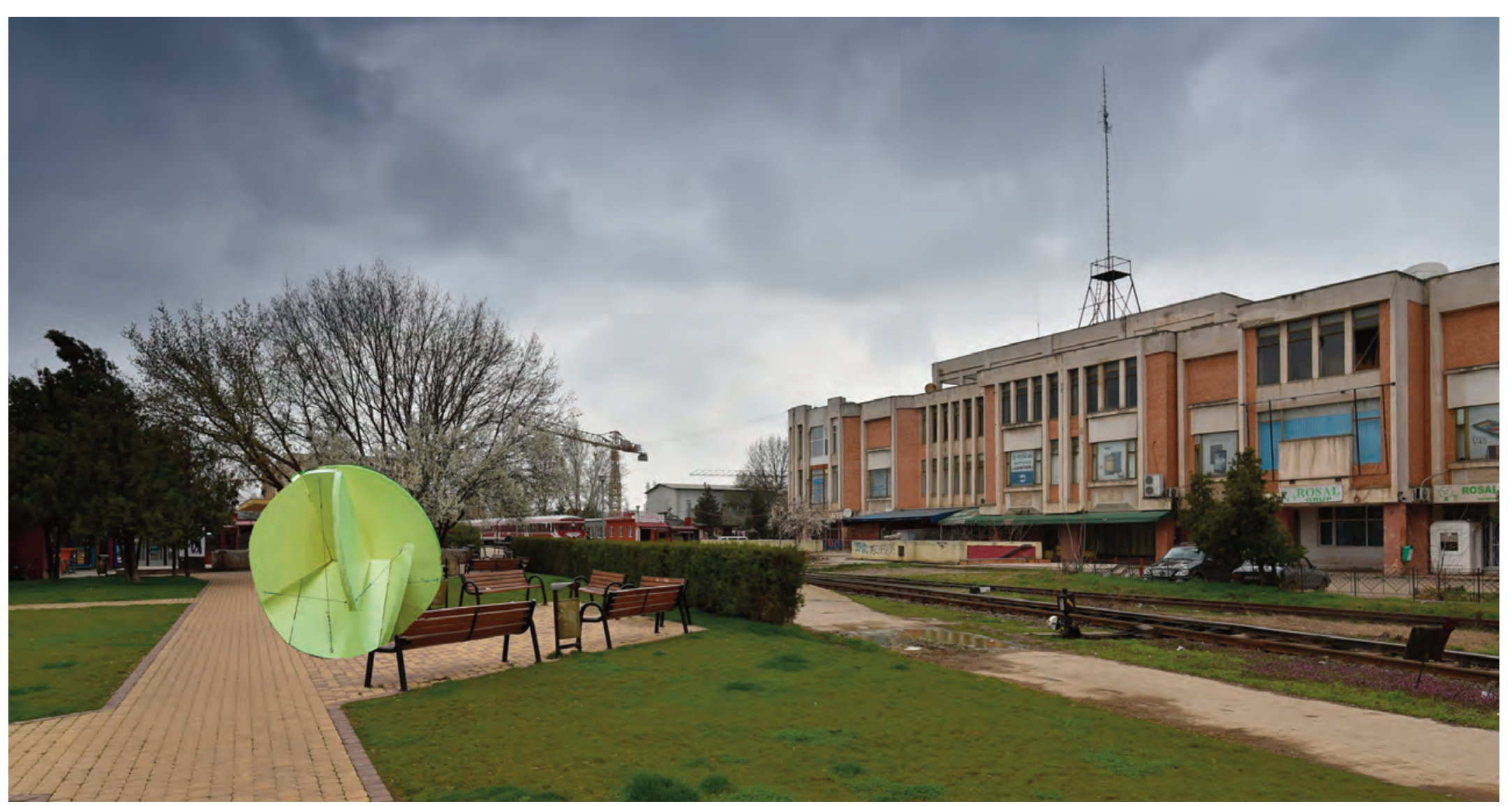

În ambele propuneri, plantările obiectelor se fac simplu, direct în mediu, cu scopul elementar de a se adresa direct trecătorilor, de a-i obișnui cu prezența obiectelor de artă în spațiul cunoscut. (propunere - Maria Boștenaru Dan)

In both proposals, the oject setting is simply made, straight in the milieu, having as a main goal the direct adress to the people, reaching to comfort them with the presence of an art object in a common space. (project - Maria Boștenaru Dan)

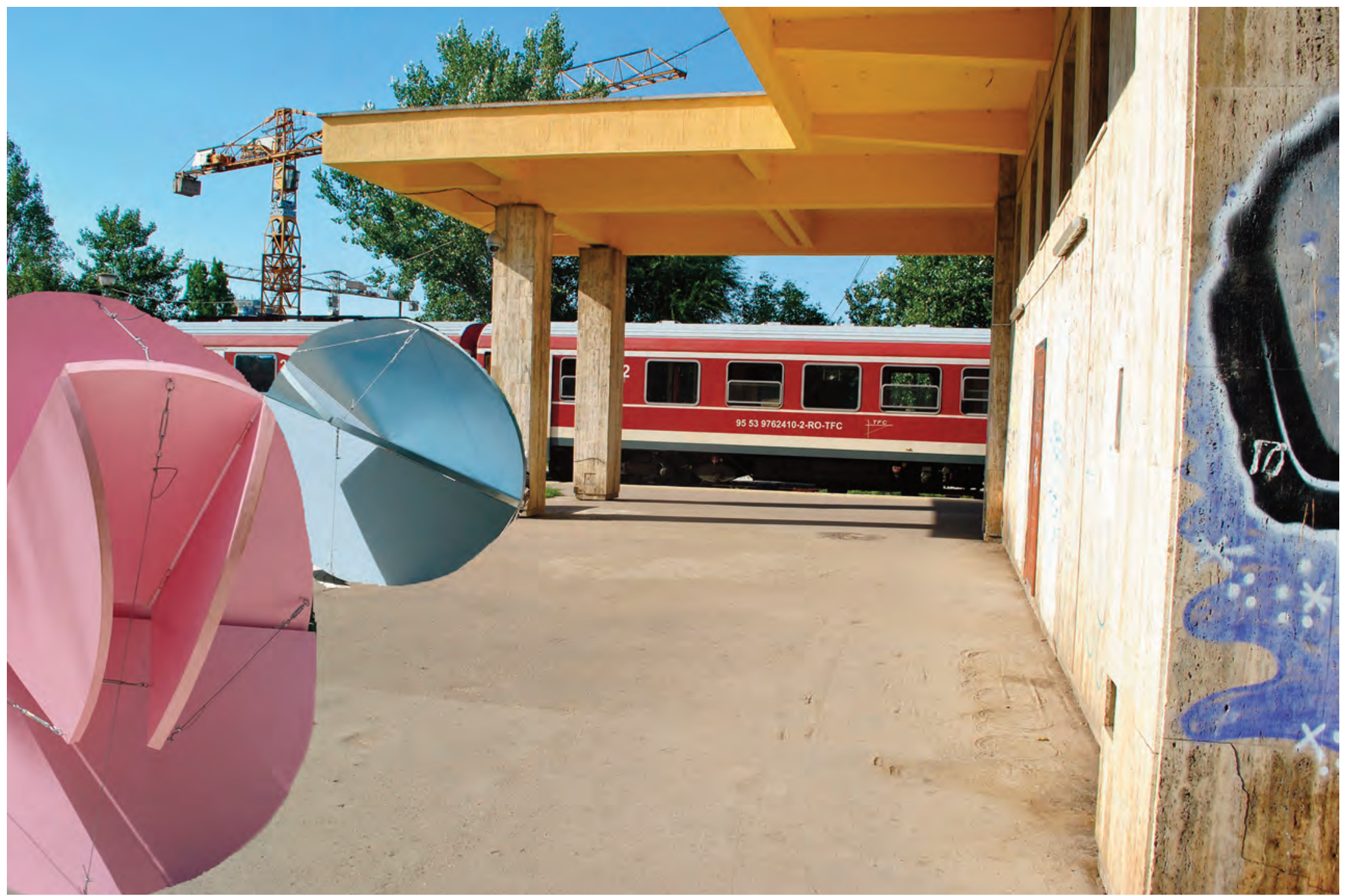

